\title{
Correction to: A vagrant black-headed Gull (Chroicocephalus ridibundus) documented from Saint Peter and Saint Paul archipelago: Brazil's first record
}

\author{
Antônio Coimbra de Brum ${ }^{1,2} \cdot$ Renata Brentano ${ }^{1} \cdot$ Rosalinda Carmela Montone $^{3} \cdot$ Maria Virginia Petry $^{1}$ \\ Published online: 25 May 2021 \\ (C) Sociedade Brasileira de Ornitologia 2021
}

\section{Correction to: Ornithology Research (2020) 28:263-266}

https://doi.org/10.1007/s43388-021-00036-3

The article A vagrant Black-headed Gull (Chroicocephalus ridibundus) documented from Saint Peter and Saint Paul Archipelago: Brazil's first record, written by Coimbra de Brum, Brentano, Montone, and Petry was originally published online on the publisher's internet portal on February 8, 2021 with Open Access under a Creative Commons Attribution (CC BY) license 4.0. With the author's/authors' decision to cancel Open Access the copyright of the article changed on May 14, 2021 to @ Sociedade Brasileira de Ornitologia 2021 with all rights reserved.

The online version of the original article can be found at https://oi.org/ $10.1007 / \mathrm{s} 43388-021-00036-3$

Maria Virginia Petry

vpetry@unisinos.br

1 Laboratório de Ornitologia e Animais Marinhos, Universidade do

Vale do Rio dos Sinos, Unisinos, São Leopoldo, RS, Brazil

2 Programa de Pós-Graduação em Biologia, Universidade do Vale do Rio dos Sinos, Unisinos, São Leopoldo, RS, Brazil

3 Laboratório de Química Orgânica Marinha, Instituto Oceanográfico, Universidade de São Paulo, São Paulo, SP, Brazil 